\title{
Transmutation Analysis of Enriched Uranium and Deep Burn High Temperature Reactors
}

Michael A. Pope

July 2012

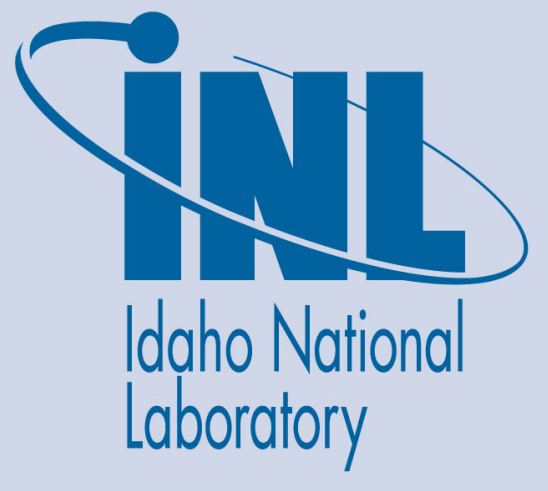

The INL is a U.S. Department of Energy National Laboratory operated by Battelle Energy Alliance 
INL/EXT-12-26423

FCR\&D-FCO-2012-000149

\title{
Transmutation Analysis of Enriched Uranium and Deep Burn High Temperature Reactors
}

\author{
Michael A. Pope
}

July 2012

\section{Idaho National Laboratory \\ Fuel Cycle Research \& Development Idaho Falls, Idaho 83415}

http://www.inl.gov

Prepared for the

U.S. Department of Energy

Office of Nuclear Energy

Under DOE Idaho Operations Office

Contract DE-AC07-05ID14517 


\section{DISCLAIMER}

This information was prepared as an account of work sponsored by an agency of the U.S. Government. Neither the U.S. Government nor any agency thereof, nor any of their employees, makes any warranty, expressed or implied, or assumes any legal liability or responsibility for the accuracy, completeness, or usefulness, of any information, apparatus, product, or process disclosed, or represents that its use would not infringe privately owned rights. References herein to any specific commercial product, process, or service by trade name, trade mark, manufacturer, or otherwise, does not necessarily constitute or imply its endorsement, recommendation, or favoring by the U.S. Government or any agency thereof. The views and opinions of authors expressed herein do not necessarily state or reflect those of the U.S. Government or any agency thereof. 
Transmutation Analysis of Enriched Uranium and Deep Burn HTRs

July 2012 


\section{SUMMARY}

High temperature gas-cooled reactors (HTRs) have been under consideration for production of electricity, process heat, and for destruction of transuranics for decades. As part of the transmutation analysis efforts within the Fuel Cycle Research and Development (FCR\&D) campaign, a need was identified for detailed discharge isotopics from HTRs for use in the VISION code. A conventional HTR using enriched uranium in UCO fuel was modeled having discharge burnup of $120 \mathrm{GWd} / \mathrm{MTiHM}$. Also, a deep burn HTR (DB-HTR) was modeled burning transuranic (TRU)-only TRU- $\mathrm{O}_{2}$ fuel to a discharge burnup of $648 \mathrm{GWd} / \mathrm{MTiHM}$. For each of these cases, unit cell depletion calculations were performed with SCALE/TRITON.

Unit cells were used to perform this analysis using SCALE 6.1. Because of the long mean free paths (and migration lengths) of neutrons in HTRs, using a unit cell to represent a whole core can be non-trivial. The sizes of these cells were first set by using Serpent calculations to match a spectral index between unit cell and whole core domains. In the case of the DB-HTR, the unit cell which was arrived at in this way conserved the ratio of fuel to moderator found in a single block of fuel. In the conventional HTR case, a larger moderator-to-fuel ratio than that of a single block was needed to simulate the whole core spectrum.

Discharge isotopics (for 500 nuclides) and one-group cross-sections (for 1022 nuclides) were delivered to the transmutation analysis team. This report provides documentation for these calculations. In addition to the discharge isotopics, one-group cross-sections were provided for the full list of 1022 nuclides tracked in the transmutation library. 


\section{CONTENTS}

SUMMARY

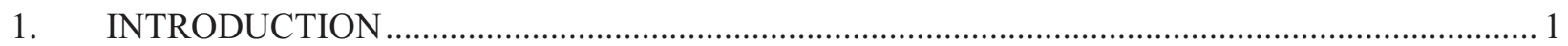

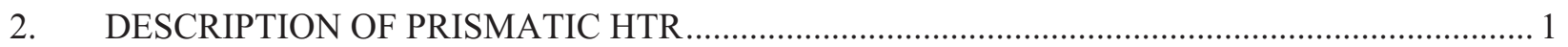

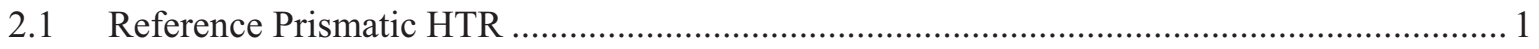

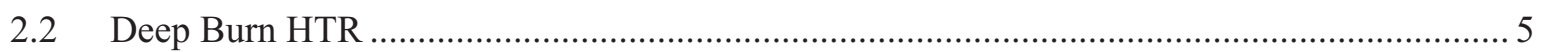

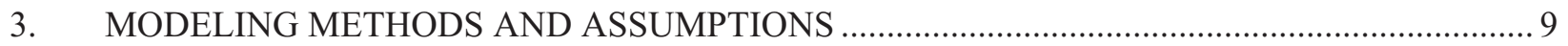

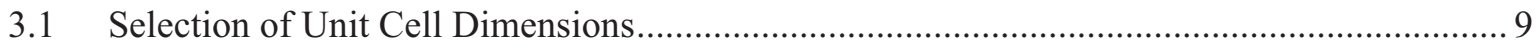

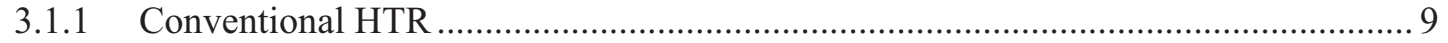

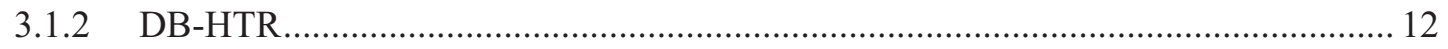

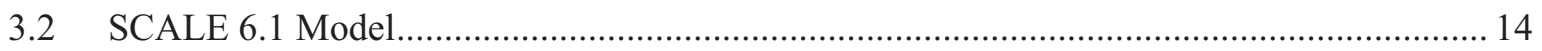

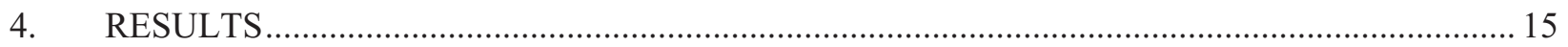

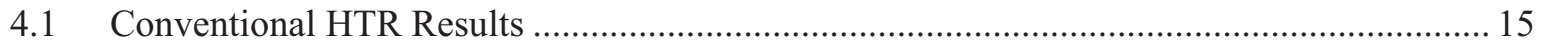

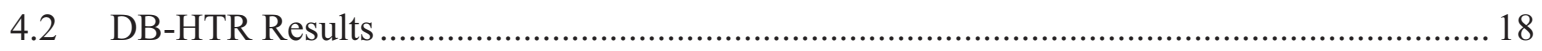

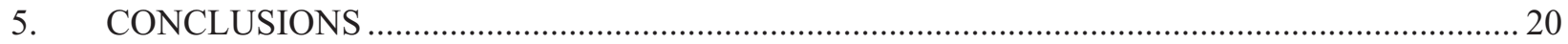

\section{FIGURES}

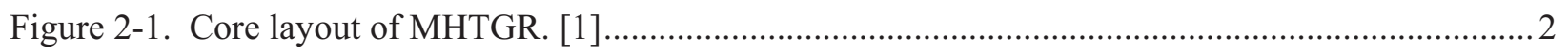

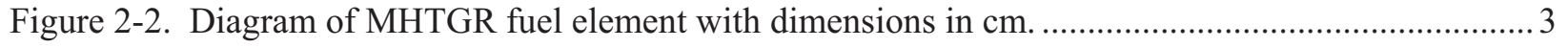

Figure 2-3. Layout of deep burn HTR (DB-HTR) core. [6] …......................................................... 6

Figure 3-1. Cutaway of Serpent model of compact with randomly distributed TRISO particles at $\mathrm{PF}=35 \%$ (hexagonal unit cell boundary not shown). ......................................................... 10

Figure 3-2. Diagram of 2D Serpent model of radial slice of HTR core ................................................. 11

Figure 3-3. Ratio of $\mathrm{c} 8 / \mathrm{f5}$ versus unit cell pitch with whole-core value shown for conventional

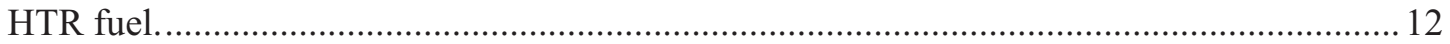

Figure 3-4. Normalized neutron flux spectra for various HTR unit cell pitches with whole-core value shown.

Figure 3-5. Cutaway of Serpent model of compact with randomly distributed TRISO particles at $\mathrm{PF}=7 \%$.

Figure 3-6. Diagram of 2D Serpent model of radial slice of DB-HTR core ....................................... 13

Figure 3-7. Ratio of $\mathrm{c} 0 / \mathrm{f} 9$ versus unit cell pitch with whole-core value shown for DB-HTR fuel............ 14

Figure 3-8. Normalized neutron flux spectra for various DB-HTR unit cell pitches with wholecore value shown. 
Figure 3-9. Unit cell constructed based on conserving the ratio of fuel compact to graphite in a single block.

Figure 4-1. $\mathrm{K}_{\infty}$ versus burnup in EFPD for enriched uranium HTR unit cell with lattice pitch = $2.23 \mathrm{~cm}$. 16

Figure 4-2. $\mathrm{K}_{\infty}$ versus burnup in GWd/MTiHM for enriched uranium HTR unit cell with lattice pitch $=2.23 \mathrm{~cm}$. 16

Figure 4-3. $\mathrm{K}_{\infty}$ versus burnup in EFPD for $\mathrm{TRU}-\mathrm{O}_{2}$ fueled DB-HTR unit cell with lattice pitch = $2.23 \mathrm{~cm}$

Figure 4-4. $\mathrm{K}_{\infty}$ versus burnup in GWd/MTiHM for TRU-O ${ }_{2}$ fueled DB-HTR unit cell with lattice pitch $=2.23 \mathrm{~cm}$.

\section{TABLES}

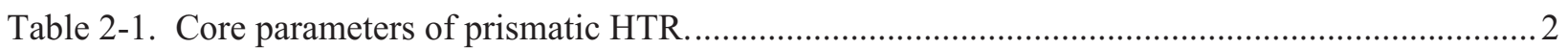

Table 2-2. Fuel block and TRISO particle properties for conventional HTR ......................................... 4

Table 2-3. Nuclide number densities for fuel block components in conventional HTR............................ 5

Table 2-4. Fuel kernel properties for $450 \mathrm{MW}_{\text {th }}$ DB-HTR fuel. ................................................................. 7

Table 2-5. Actinide mass fractions for input fuel vector in prismatic DB-HTR....................................... 8

Table 2-6. Nuclide number densities for fuel kernels in DB- HTR unit cell. ............................................ 9

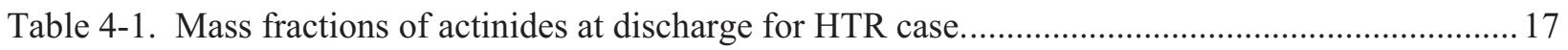

Table 4-2. Conversion ratios for conventional HTR unit cell................................................................... 18

Table 4-3. Mass fractions of actinides at discharge for DB-HTR case ...................................................2 20

Table 4-4. Conversion ratios for DB-HTR unit cell. ............................................................................ 20 


\section{ACRONYMS}

$\begin{array}{ll}\text { AGR } & \text { Advanced Gas Reactor } \\ \text { BOL } & \text { Beginning of Life } \\ \text { DB-HTR } & \text { Deep Burn High Temperature Reactor } \\ \text { EOL } & \text { End of Life (discharge) } \\ \text { GA } & \text { General Atomics } \\ \text { GWd/MTiHM } & \text { Gigawatt-days per tonne of initial heavy metal } \\ \text { HTR } & \text { High Temperature Reactor } \\ \text { INL } & \text { Idaho National Laboratory } \\ \text { MHTGR } & \text { Modular High Temperature Gas Reactor } \\ \text { PF } & \text { Packing Fraction } \\ \text { TRISO } & \text { Tri-isotropic } \\ \text { TRU } & \text { Transuranics }\end{array}$





\section{TRANSMUTATION ANALYSIS OF ENRICHED URNANIUM AND DEEP BURN HIGH TEMPERATURE REACTORS}

\section{INTRODUCTION}

High temperature reactors (HTRs) have been under consideration for production of electricity, process heat, and for destruction of transuranics for decades. As part of the transmutation analysis efforts within the Fuel Cycle Research and Development (FCR\&D) campaign, a need was identified for detailed discharge isotopics from HTRs for use in the VISION code. [1] In addition to the discharge isotopics, one-group cross-sections were requested for the full list of 1022 nuclides tracked in the transmutation library. A conventional HTR using enriched uranium in UCO fuel was modeled having discharge burnup of $120 \mathrm{GWd}$ /MTiHM. Also, a deep burn HTR (DB-HTR) was modeled burning transuranic (TRU)-only TRU-O $\mathrm{O}_{2}$ fuel to a discharge burnup of $648 \mathrm{GWd} / \mathrm{MTiHM}$. For each of these cases, unit cell depletion calculations were performed with SCALE/TRITON. [2] Discharge isotopics (for 500 nuclides) and onegroup cross-sections (for 1022 nuclides) were delivered to the transmutation analysis team. This report provides documentation for these calculations.

\section{DESCRIPTION OF PRISMATIC HTR}

\subsection{Reference Prismatic HTR}

The reference prismatic HTR selected for analysis was derived from the $350 \mathrm{MWth}$ General Atomics (GA) Modular High Temperature Gas Reactor (MHTGR 350). This reactor concept has been under development intermittently since the 1980s and remains the basis for current prismatic HTR concepts today. The MHTGR 350 is also the basis for an international benchmark underway coordinated the Idaho National Laboratory (INL), the documentation of which was used as a source for many of the reactor parameters assumed here. [3] Table 2-1 shows basic core parameters for this reactor such as core size, inlet and outlet temperatures, etc. This core consists of fuel in graphite blocks arranged in an annular configuration as shown in Figure 2-1. An inner and an outer reflector region are used, which are comprised of graphite blocks shown in gray in the figure. Figure 2-2 shows a diagram of the fuel block used for this work. Fuel compacts and coolant channels are arranged with a pitch of $1.88 \mathrm{~cm}$. Ordinarily, the corner locations would contain burnable poisons, but these are not considered here as the design is evolving and this simplification does not have a large impact on the results of a study on discharge isotopics. The block flat-to-flat dimension is $36 \mathrm{~cm}$. It should be noted that the fully detailed design has different block types with some including various types of control rod holes. For this work, the standard element shown in Figure 2-2 is assumed and for the purpose of mass balances, the total number of compacts in the core from Ref. [3] $\left(2.03 \times 10^{6}\right)$ was used to determine core loading. 
Table 2-1. Core parameters of prismatic HTR.

\begin{tabular}{|l|c|}
\hline TRISO Particle Properties & $\begin{array}{c}\text { Value } \\
\text { Unit }\end{array}$ \\
\hline \hline Installed Thermal Capacity & $350 \mathrm{MW}_{\text {th }}$ \\
\hline Installed Electrical Capacity & $165 \mathrm{MW}_{\mathrm{e}}$ \\
\hline Primary Coolant & Helium \\
\hline Primary coolant pressure & $6.39 \mathrm{MPa}$ \\
\hline Moderator & Graphite \\
\hline Core outlet temperature & $687^{\circ} \mathrm{C}$ \\
\hline Core inlet temperature & $259^{\circ} \mathrm{C}$ \\
\hline Mass Flow Rate & $157.1 \mathrm{~kg} / \mathrm{s}$ \\
\hline Reactor Vessel Height & $22 \mathrm{~m}$ \\
\hline Reactor Vessel Outside Diameter & $6.8 \mathrm{~m}$ \\
\hline
\end{tabular}

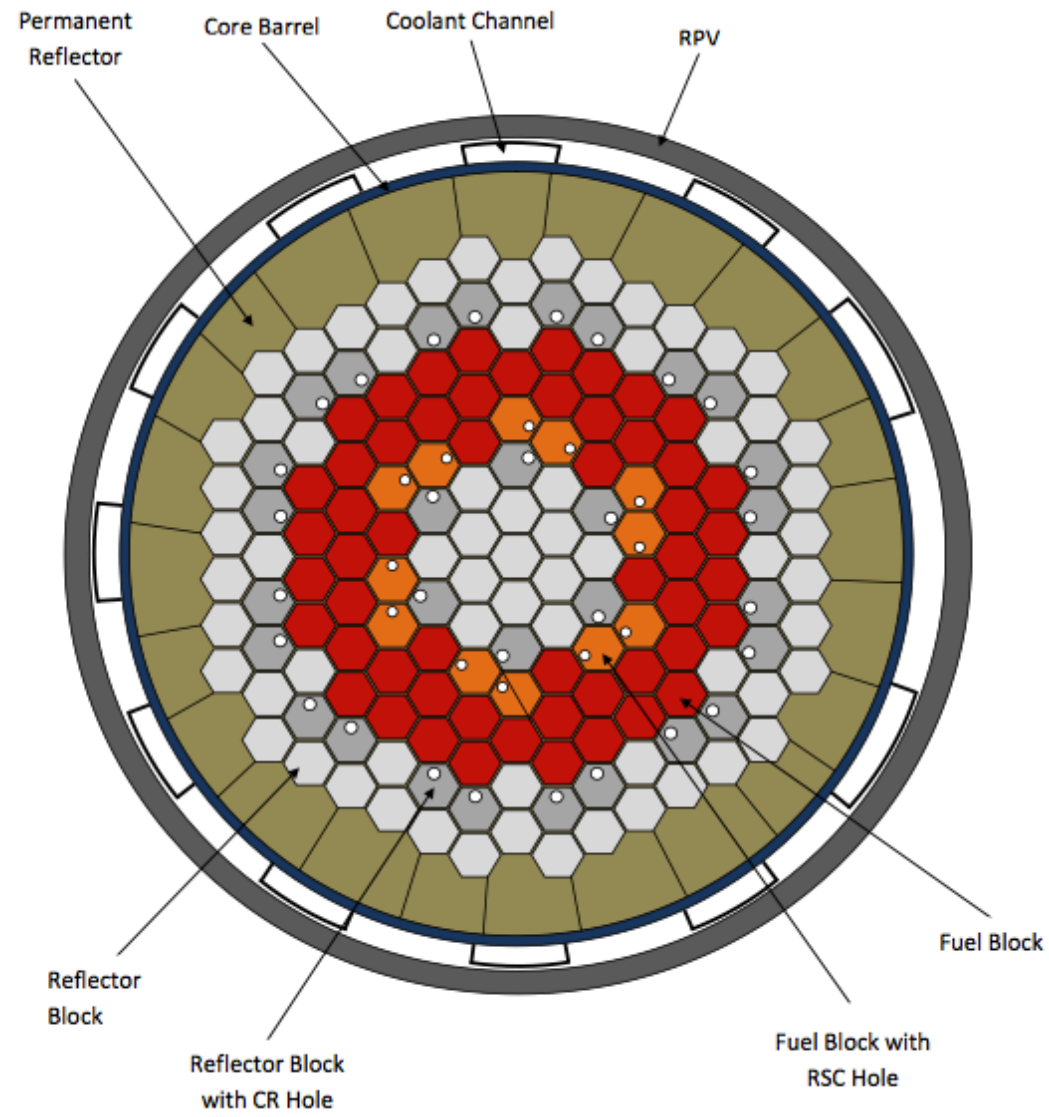

Figure 2-1. Core layout of MHTGR. [1] 


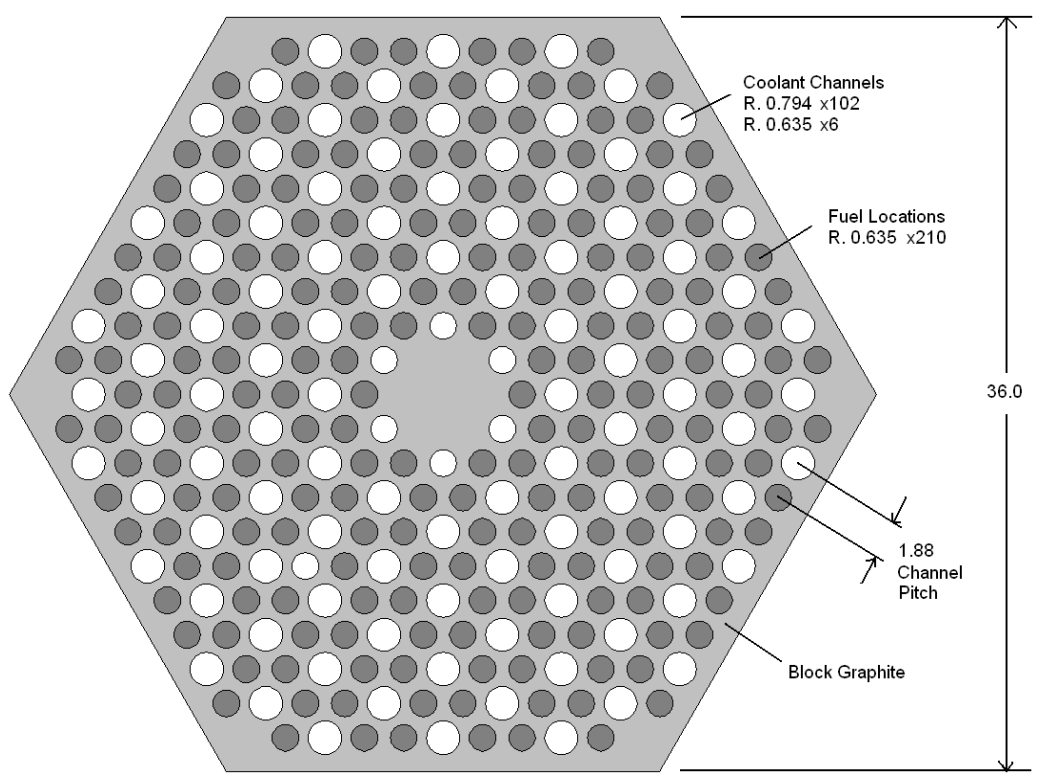

Figure 2-2. Diagram of MHTGR fuel element with dimensions in $\mathrm{cm}$.

The fuel compacts have a radius of $0.625 \mathrm{~cm}$, a height of $4.928 \mathrm{~cm}$, and contain Tri-isotropic (TRISO) fuel particles. The TRISO particles consist of a fuel kernel having a $425 \mu \mathrm{m}$ diameter coated with a $100 \mu \mathrm{m}$-thick porous carbon buffer layer for accommodation of fission product gases.

Surrounding this are a $40 \mu \mathrm{m}$-thick inner pyrolytic carbon layer (IPyC), a $35 \mu \mathrm{m}$-thick SiC pressure boundary, and another $40 \mu \mathrm{m}$-thick outer pyrolytic carbon layer (OPyC). The dimensions of the TRISO particles used along with mass densities of each are given in Table 2-2. The fuel kernel is $\mathrm{UC}_{0.5} \mathrm{O}_{1.5}$ with a density of $10.9 \mathrm{~g} / \mathrm{cm}^{3}$ and a ${ }^{235} \mathrm{U}$ enrichment of $15.5 \mathrm{w} / \mathrm{o}$. The TRISO dimensions were taken from the "LEU-09" variant of the fuel currently being irradiated as part of the Advanced Gas Reactor-2 (AGR-2) fuel qualification work at INL. [4] The packing fraction (PF) of TRISO particles in the graphite matrix was taken to be $35 \%$. 
Table 2-2. Fuel block and TRISO particle properties for conventional HTR.

\begin{tabular}{|c|c|c|}
\hline TRISO Particle Properties & Value & Unit \\
\hline Fissile material & $\mathrm{UC}_{0.5} \mathrm{O}_{1.5}$ & \\
\hline Enrichment (U-235 average) & 15.5 & wt\% \\
\hline \multicolumn{3}{|l|}{ TRISO Particle Outer Radii (cm) } \\
\hline Kernel & 0.02125 & $\mathrm{~cm}$ \\
\hline Buffer & 0.03125 & $\mathrm{~cm}$ \\
\hline IPyC & 0.03525 & $\mathrm{~cm}$ \\
\hline $\mathrm{SiC}$ & 0.03875 & $\mathrm{~cm}$ \\
\hline OPyC & 0.04275 & $\mathrm{~cm}$ \\
\hline \multicolumn{3}{|l|}{ TRISO Particle Layer Densities $\left(\mathrm{g} / \mathrm{cm}^{3}\right)$} \\
\hline Kernel & 10.9 & $\mathrm{~g} / \mathrm{cm}^{3}$ \\
\hline Buffer & 1.0 & $\mathrm{~g} / \mathrm{cm}^{3}$ \\
\hline IPyC & 1.9 & $\mathrm{~g} / \mathrm{cm}^{3}$ \\
\hline $\mathrm{SiC}$ & 3.2 & $\mathrm{~g} / \mathrm{cm}^{3}$ \\
\hline OPyC & 1.9 & $\mathrm{~g} / \mathrm{cm}^{3}$ \\
\hline Particle Packing Fraction (average) & 0.35 & \\
\hline \multicolumn{3}{|l|}{ Block Properties } \\
\hline Compact Radius & 0.625 & $\mathrm{~cm}$ \\
\hline Compact Height & 4.928 & $\mathrm{~cm}$ \\
\hline Number of Compacts in Core & $2.03 \mathrm{E}+06$ & - \\
\hline Power per compact & 172 & W \\
\hline Specific Power & 67.5 & W/gHM \\
\hline Compact Hole Radius & 0.635 & $\mathrm{~cm}$ \\
\hline Number of Fuel Compact locations & 210 & - \\
\hline Large Coolant Hole Radius & 0.794 & $\mathrm{~cm}$ \\
\hline Number of Large Coolant Holes & 102 & - \\
\hline Small Coolant Hole Radius & 0.635 & $\mathrm{~cm}$ \\
\hline Number of Small Coolant Holes & 6 & - \\
\hline Block Flat to Flat Dimension & 36.0 & $\mathrm{~cm}$ \\
\hline Block Pitch & 36.2 & $\mathrm{~cm}$ \\
\hline
\end{tabular}

Table 2-3 shows nuclide number densities for the various regions used in the modeling of this system. Reflector blocks are modeled as graphite having reduced density to account for the helium coolant channels, which are essentially transparent to neutrons. 
Table 2-3. Nuclide number densities for fuel block components in conventional HTR.

\begin{tabular}{|c|c|}
\hline $\begin{array}{l}\text { Region and } \\
\text { Nuclide }\end{array}$ & $\begin{array}{c}\text { Number Density } \\
\text { (atoms/b·cm) }\end{array}$ \\
\hline Kernel & \\
\hline U-234 & $7.87 \mathrm{E}-05$ \\
\hline U-235 & $3.91 \mathrm{E}-03$ \\
\hline U-236 & $8.14 \mathrm{E}-06$ \\
\hline U-238 & $2.10 \mathrm{E}-02$ \\
\hline O-16 & $3.40 \mathrm{E}-02$ \\
\hline C-12 (free) & $8.13 \mathrm{E}-03$ \\
\hline Buffer & \\
\hline C-12 (graphite) & $5.02 \mathrm{E}-02$ \\
\hline IPyC & \\
\hline C-12 (graphite) & $9.53 \mathrm{E}-02$ \\
\hline SiC & \\
\hline Si-28 & $4.43 \mathrm{E}-02$ \\
\hline Si-29 & $2.25 \mathrm{E}-03$ \\
\hline Si-30 & $1.49 \mathrm{E}-03$ \\
\hline C-12 (free) & $4.81 \mathrm{E}-02$ \\
\hline Matrix & \\
\hline C-12 (graphite) & $8.53 \mathrm{E}-02$ \\
\hline Gaps & \\
\hline He-4 & $7.00 \mathrm{E}-04$ \\
\hline Reflector Blocks & \\
\hline C-12 (graphite) & $9.28 \mathrm{E}-02$ \\
\hline
\end{tabular}

\subsection{Deep Burn HTR}

The prismatic DB-HTR concept involves burning TRU-only fuel in TRISO particles in an HTR. While this concept remains somewhat less mature than the conventional prismatic HTR designs, much work has been performed in recent years evaluating this option. [6] The fuel proposed in the DB-HTR concept differs from that of the conventional enriched uranium-fueled HTR in several ways. For one, the fuel blocks comprising the active core are arranged in five rings of fuel elements rather than three, leading to 144 fuel columns as opposed to the 66 in the conventional HTR from Section 2.1. The additional two rings of fuel reduce leakage and extend the discharge burnup. This layout is shown in Figure 2-3. The active core height is $793 \mathrm{~cm}$, the same as the conventional HTR. The reactor power of the DB-HTR was reduced to $450 \mathrm{MW}_{\text {th }}$ in order to tolerate accident conditions. [6] The net result of the factor of nearly two more fuel blocks and a slightly higher total power is a lower power density than in the case of the conventional HTR. The kernel size is reduced in order to reduce self-shielding and extend burnup further. The fuel meat in the kernels is stoichiometric transuranic oxide $\left(\mathrm{TRU}-\mathrm{O}_{2}\right)$. In order to reduce the pressure in the buffer, $\mathrm{SiC}$ is mixed into the kernel to serve as an oxygen getter. The $\mathrm{SiC}$ getter occupies $25 \%$ of 
the kernel by volume. Several PF values were evaluated in Reference [6]. The fuel used here is modeled after Case 9 from Table 4 of this reference. No burnable poisons are assumed here for simplicity and the fuel block dimensions are the same as the reference HTR described in Section 2.1. Table 2-4 shows the properties of the DB-HTR fuel kernels and fuel blocks and Table 2-5 shows the actinide mass fractions for the input feed.

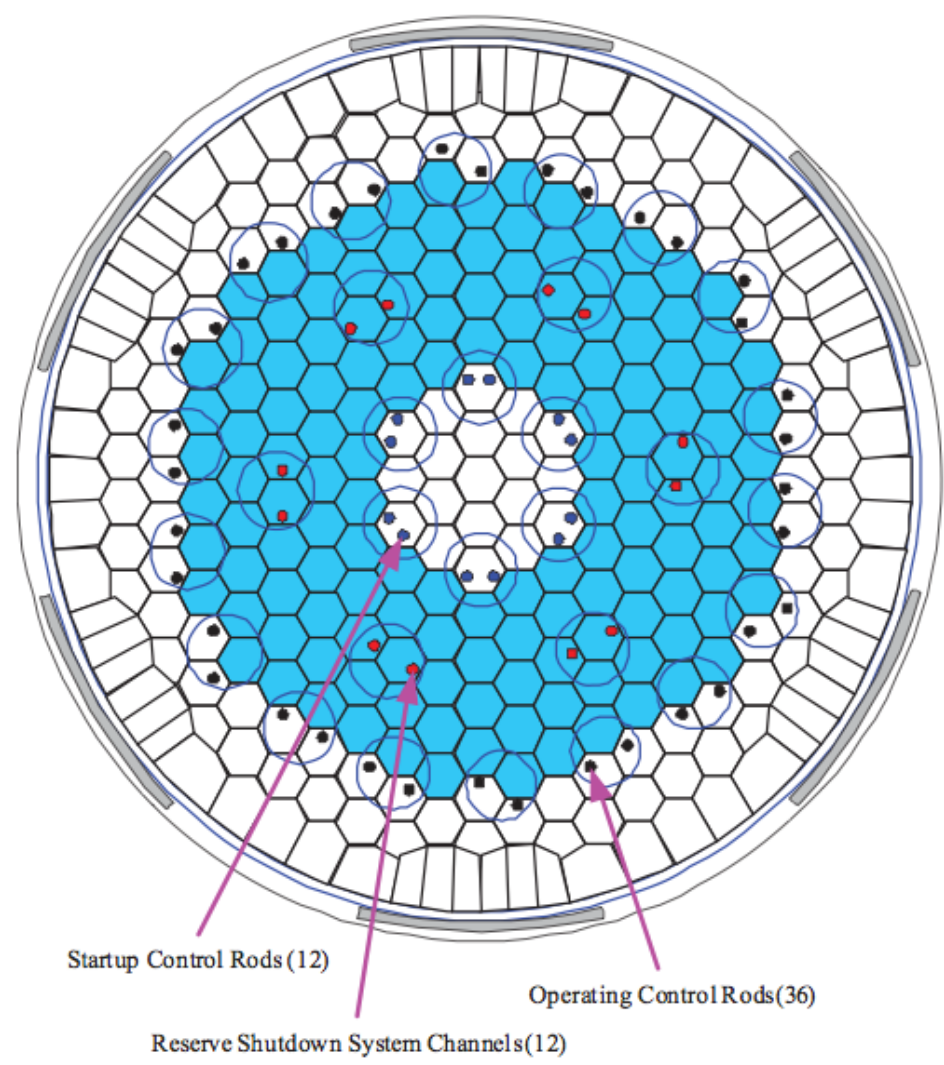

Figure 2-3. Layout of deep burn HTR (DB-HTR) core. [6]

The DB-HTR fuel feed comes from once-burned used fuel from a Pressurized Water Reactor (PWR) having a burnup of $50 \mathrm{GWd} / \mathrm{THM}$. In order to arrive at the input mass fractions for the DB-LWR, the output from the PWR having burnup of $50 \mathrm{GWd} / \mathrm{THM}$ was allowed to decay for 5 years at zero power. Then, all nuclides were removed except the TRU, followed by another 2 years of decay at zero power. Nuclides with mass fractions below $10^{-6}$ were omitted from the feed stream. These calculations were performed using a decay tool by Piet [7]. The resulting TRU vector was then used to develop the TRU$\mathrm{O}_{2}$ input to the DB-HTR unit cell. The resulting actinide mass fractions are given in Table 2-5 and the number densities of the nuclides in the mixture of TRU-O $\mathrm{O}_{2}$ and $\mathrm{SiC}$ getter used in the kernels is given in Table 2-6. 
Table 2-4. Fuel kernel properties for $450 \mathrm{MW}_{\text {th }}$ DB-HTR fuel.

\begin{tabular}{|c|c|c|}
\hline TRISO Particle Properties & Value & Unit \\
\hline Fissile material & $\mathrm{TRU}-\mathrm{O}_{2}$ & - \\
\hline Oxygen Getter & $\mathrm{SiC}$ & - \\
\hline Oxygen Getter Nominal Density & 3.2 & $\mathrm{~g} / \mathrm{cm}$ \\
\hline Getter volume fraction & 25 & $\%$ \\
\hline \multicolumn{3}{|l|}{ TRISO Particle Outer Radii (cm) } \\
\hline Kernel & 0.0175 & $\mathrm{~cm}$ \\
\hline Buffer & 0.0275 & $\mathrm{~cm}$ \\
\hline IPyC & 0.0310 & $\mathrm{~cm}$ \\
\hline $\mathrm{SiC}$ & 0.0345 & $\mathrm{~cm}$ \\
\hline OPyC & 0.0385 & $\mathrm{~cm}$ \\
\hline \multicolumn{3}{|l|}{ TRISO Particle Layer Densities $\left(\mathrm{g} / \mathrm{cm}^{3}\right)$} \\
\hline Kernel & 10.0 & $\mathrm{~g} / \mathrm{cm}^{3}$ \\
\hline Buffer & 1.0 & $\mathrm{~g} / \mathrm{cm}^{3}$ \\
\hline IPyC & 1.9 & $\mathrm{~g} / \mathrm{cm}^{3}$ \\
\hline $\mathrm{SiC}$ & 3.2 & $\mathrm{~g} / \mathrm{cm}^{3}$ \\
\hline OPyC & 1.9 & $\mathrm{~g} / \mathrm{cm}^{3}$ \\
\hline Particle Packing Fraction (average) & 0.07 & \\
\hline \multicolumn{3}{|l|}{ Block Properties } \\
\hline Compact Radius & 0.625 & $\mathrm{~cm}$ \\
\hline Compact Height & 4.928 & $\mathrm{~cm}$ \\
\hline Number of Compacts in Entire Core & $4.43 E+06$ & - \\
\hline Power per compact & 101 & W \\
\hline Specific Power & 383.9 & $\mathrm{~W} / \mathrm{gHM}$ \\
\hline Compact Hole Radius & 0.635 & $\mathrm{~cm}$ \\
\hline Number of Fuel Compact Locations & 210 & - \\
\hline Large Coolant Hole Radius & 0.794 & $\mathrm{~cm}$ \\
\hline Number of Large Coolant Holes & 102 & - \\
\hline Small Coolant Hole Radius & 0.635 & $\mathrm{~cm}$ \\
\hline Number of Small Coolant Holes & 6 & - \\
\hline Block Flat to Flat Dimension & 36.0 & $\mathrm{~cm}$ \\
\hline Block Pitch & 36.2 & $\mathrm{~cm}$ \\
\hline
\end{tabular}


Table 2-5. Actinide mass fractions for input fuel vector in prismatic DB-HTR.

\begin{tabular}{|l|c|}
\hline HM Nuclide & $\begin{array}{l}\text { Mass } \\
\text { Fraction }\end{array}$ \\
\hline U-234 & $3.65 \mathrm{E}-04$ \\
\hline U-235 & $2.69 \mathrm{E}-05$ \\
\hline U-236 & $4.70 \mathrm{E}-05$ \\
\hline Np-237 & $4.81 \mathrm{E}-02$ \\
\hline Pu-238 & $2.33 \mathrm{E}-02$ \\
\hline Pu-239 & $4.75 \mathrm{E}-01$ \\
\hline Pu-240 & $2.26 \mathrm{E}-01$ \\
\hline Pu-241 & $9.68 \mathrm{E}-02$ \\
\hline Pu-242 & $6.67 \mathrm{E}-02$ \\
\hline Pu-244 & $2.21 \mathrm{E}-06$ \\
\hline Am-241 & $4.35 \mathrm{E}-02$ \\
\hline Am-242m & $6.38 \mathrm{E}-05$ \\
\hline Am-243 & $1.53 \mathrm{E}-02$ \\
\hline Cm-243 & $5.02 \mathrm{E}-05$ \\
\hline Cm-244 & $5.06 \mathrm{E}-03$ \\
\hline Cm-245 & $4.41 \mathrm{E}-04$ \\
\hline Cm-246 & $5.62 \mathrm{E}-05$ \\
\hline Total & $1.00 \mathrm{E}+00$ \\
\hline
\end{tabular}


Table 2-6. Nuclide number densities for fuel kernels in DB- HTR unit cell.

\begin{tabular}{|l|c|}
\hline Region and Nuclide & $\begin{array}{l}\text { Number Density } \\
\text { (atoms/b·cm) }\end{array}$ \\
\hline U-234 & $6.209 \mathrm{E}-06$ \\
\hline U-235 & $4.560 \mathrm{E}-07$ \\
\hline U-236 & $7.935 \mathrm{E}-07$ \\
\hline Np-237 & $8.079 \mathrm{E}-04$ \\
\hline Pu-238 & $3.900 \mathrm{E}-04$ \\
\hline Pu-239 & $7.914 \mathrm{E}-03$ \\
\hline Pu-240 & $3.745 \mathrm{E}-03$ \\
\hline Pu-241 & $1.601 \mathrm{E}-03$ \\
\hline Pu-242 & $1.097 \mathrm{E}-03$ \\
\hline Pu-244 & $3.609 \mathrm{E}-08$ \\
\hline Am-241 & $7.188 \mathrm{E}-04$ \\
\hline Am-242m & $1.050 \mathrm{E}-06$ \\
\hline Am-243 & $2.511 \mathrm{E}-04$ \\
\hline $\mathrm{Cm}-243$ & $8.226 \mathrm{E}-07$ \\
\hline $\mathrm{Cm}-244$ & $8.268 \mathrm{E}-05$ \\
\hline $\mathrm{Cm}-245$ & $7.175 \mathrm{E}-06$ \\
\hline $\mathrm{Cm}-246$ & $9.108 \mathrm{E}-07$ \\
\hline $\mathrm{O}-16$ & $3.325 \mathrm{E}-02$ \\
\hline Si-28 & $1.108 \mathrm{E}-02$ \\
\hline Si-29 & $5.625 \mathrm{E}-04$ \\
\hline Si-30 & $3.725 \mathrm{E}-04$ \\
\hline $\mathrm{C}-12$ (free) & $1.203 \mathrm{E}-02$ \\
\hline
\end{tabular}

\section{MODELING METHODS AND ASSUMPTIONS}

\subsection{Selection of Unit Cell Dimensions}

\subsubsection{Conventional HTR}

It is well known that the large neutron mean free paths in HTRs lead to difficulty capturing an appropriate spectrum in small-domain lattice calculations. [8] However, modeling and depleting an entire core model in order to arrive at a "generic" set of mass flows representing HTR fuel is not practical. Therefore, a single unit cell should be developed which captures the average fuel behavior of the core.

In order to accomplish this, models were developed using the Monte Carlo code Serpent. [7] This code has similar functionality to MCNP [10] with a unique feature relevant to this work. Specifically, random arrangements of microstructures can be generated by the Serpent wherein a fixed lattice of 
explicitly modeled TRISO particles can be placed in fuel compacts. A cutaway of a compact having $35 \%$ PF is shown in Figure 3-1. Several models of the conventional HTR fuel were generated in Serpent. One of these was a $2 \mathrm{~cm}$ tall slice of the core with the entire domain modeled radially. A diagram of this model is given in Figure 3-2. Periodic boundary conditions were placed at the axial top and bottom of the model making it infinite in the axial direction. This assumption is quite adequate for tall thin cores such as this one. This model was used to calculate whole-core averaged ratio of capture in ${ }^{238} \mathrm{U}$ to fission in ${ }^{235} \mathrm{U}(\mathrm{c} 8 / \mathrm{f5})$. This was selected as the spectral index of interest because it is an indicator of the amount of heavy metal that is converted to plutonium per the amount of thermal power produced. Then, single fuel compact Serpent models were constructed having the same fuel, but with varying pitch of the effective hexagonal unit cell. Reflective boundary conditions were applied to the radial boundaries. This pitch was varied until the same $\mathrm{c} 8 / \mathrm{f5}$ ratio was calculated as in the whole core model. This was taken to be the indicator that an "effective" unit cell has been achieved that would most closely represent the whole-core average condition.

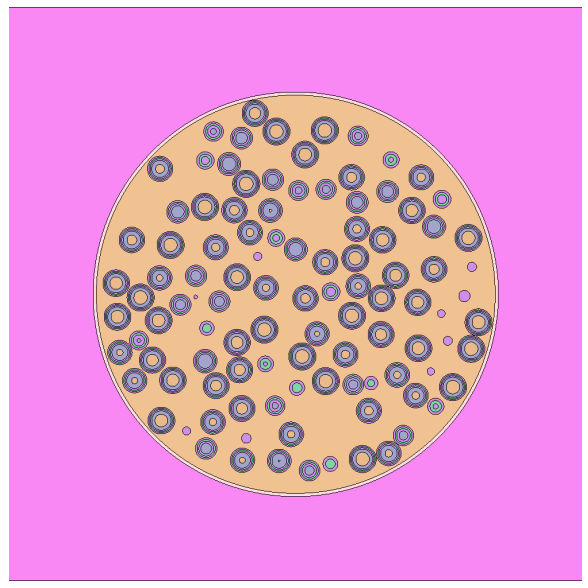

Figure 3-1. Cutaway of Serpent model of compact with randomly distributed TRISO particles at PF=35\% (hexagonal unit cell boundary not shown). 


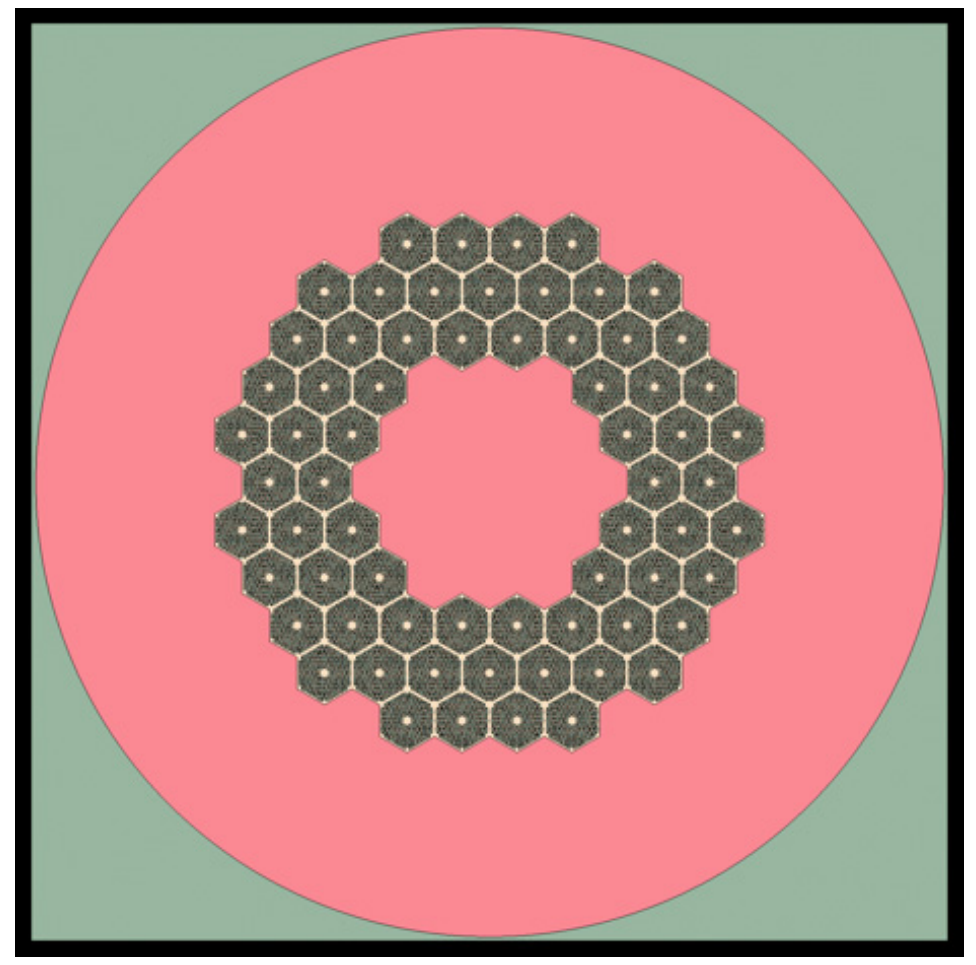

Figure 3-2. Diagram of 2D Serpent model of radial slice of HTR core.

Figure 3-3 shows the $\mathrm{c} 8 / \mathrm{f5}$ ratio versus flat-to-flat unit cell dimension (pitch). The smallest pitch $(1.88 \mathrm{~cm})$ represents the actual pitch of fuel and coolant channels in a fuel block. The next value $(2.23$ $\mathrm{cm}$ ) is the effective unit cell pitch that conserves the ratio of fuel compact to moderator in a single fuel block. The dashed line represents the whole-core average value calculated using the whole-core Serpent model. It appears from this data that a unit cell pitch of $2.5 \mathrm{~cm}$ is a reasonable approximation to the relevant spectral conditions of the full core. Figure 3-4 shows the neutron spectrum in fuel kernels for the whole core and three unit cell sizes. This shows that even in the case of the unit cell having $2.5 \mathrm{~cm}$ pitch, which matches the selected spectral index of the whole core, an exactly matched spectrum over the entire range of energy is not achieved with the domain used here. Nevertheless, this unit cell is sized such that the resulting depletion behavior would be expected to match more closely the core-averaged behavior than either of the unit cells derived from single-block dimensions. The unit cell having a pitch of $2.5 \mathrm{~cm}$ is thus carried forward to subsequent depletion calculations in the conventional enriched uranium HTR core. 


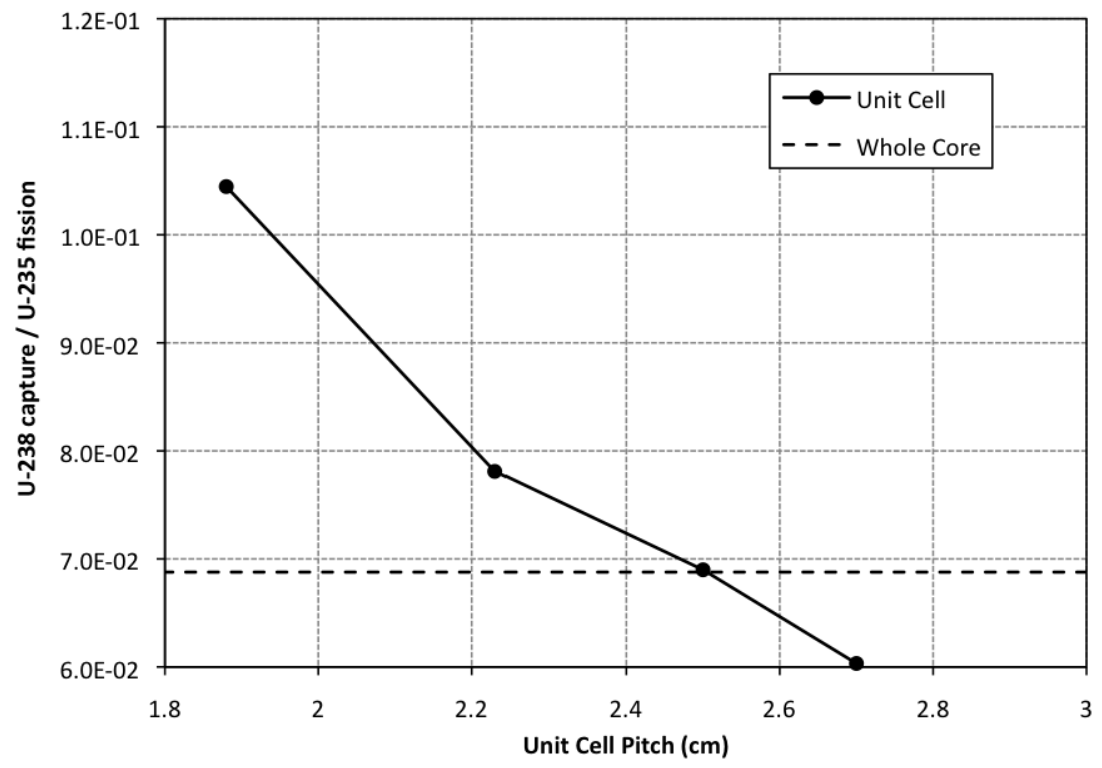

Figure 3-3. Ratio of $\mathrm{c} 8 / \mathrm{f5}$ versus unit cell pitch with whole-core value shown for conventional HTR fuel.

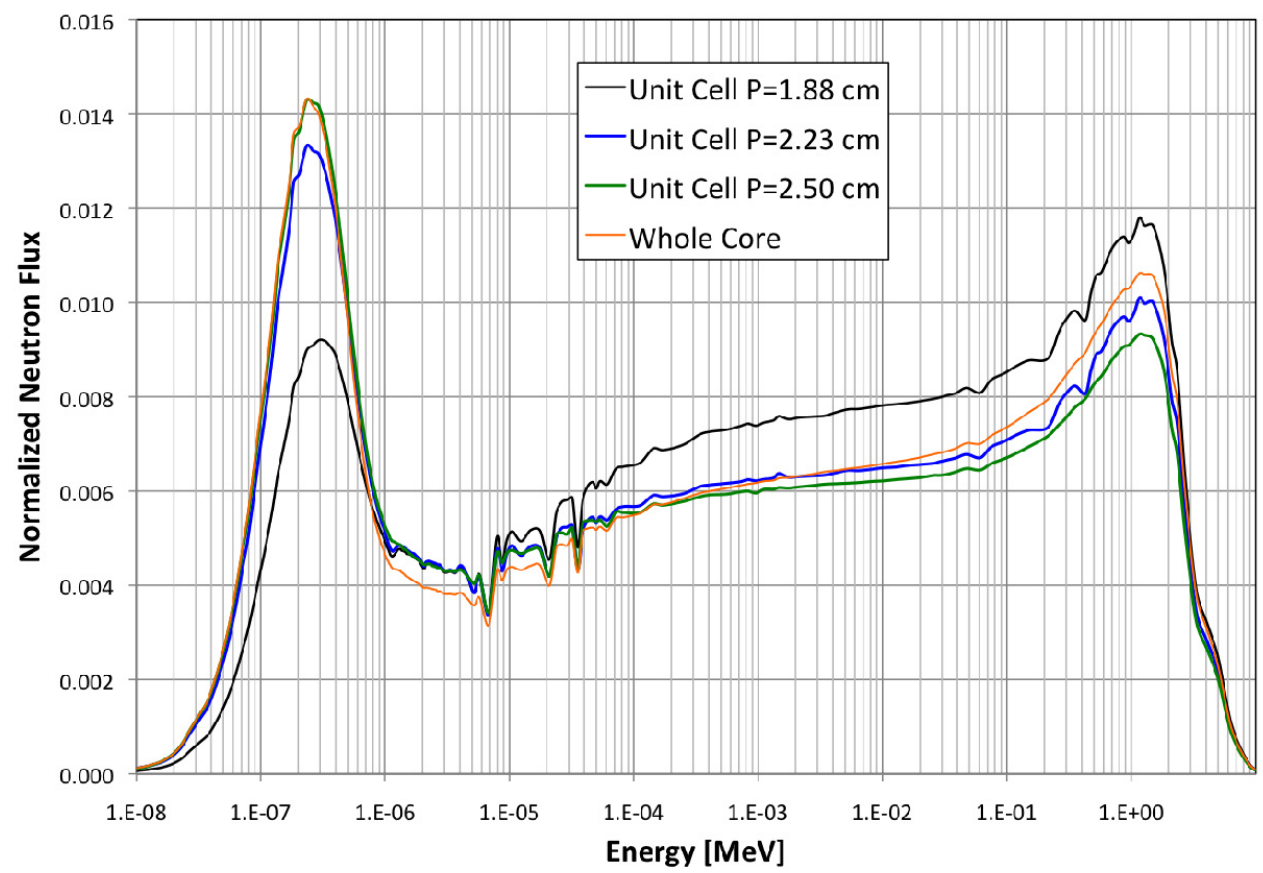

Figure 3-4. Normalized neutron flux spectra for various HTR unit cell pitches with whole-core value shown.

\subsubsection{DB-HTR}

In order to arrive at an effective pitch of the DB-HTR unit cell, the same procedure was followed as is described in Section 3.1.1. Figure 3-5 shows a cutaway of the Serpent model of a fuel compact containing TRISO particles having kernel diameter of $350 \mu \mathrm{m}$ and a PF of $7 \%$ using the random 
dispersion functionality in Serpent. This was modeled both in a hexagonal unit cell and in the 2D core model shown in Figure 3-6.

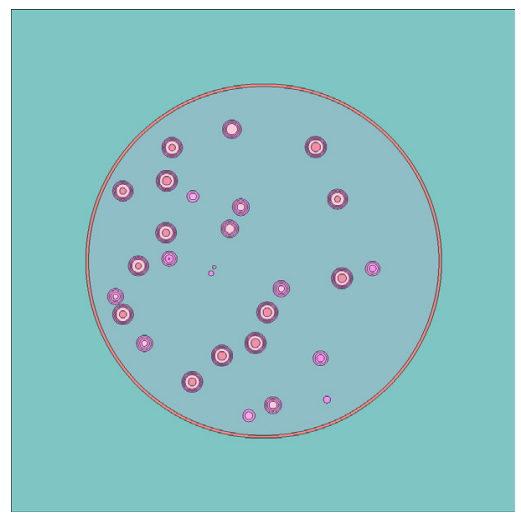

Figure 3-5. Cutaway of Serpent model of compact with randomly distributed TRISO particles at PF=7\%.

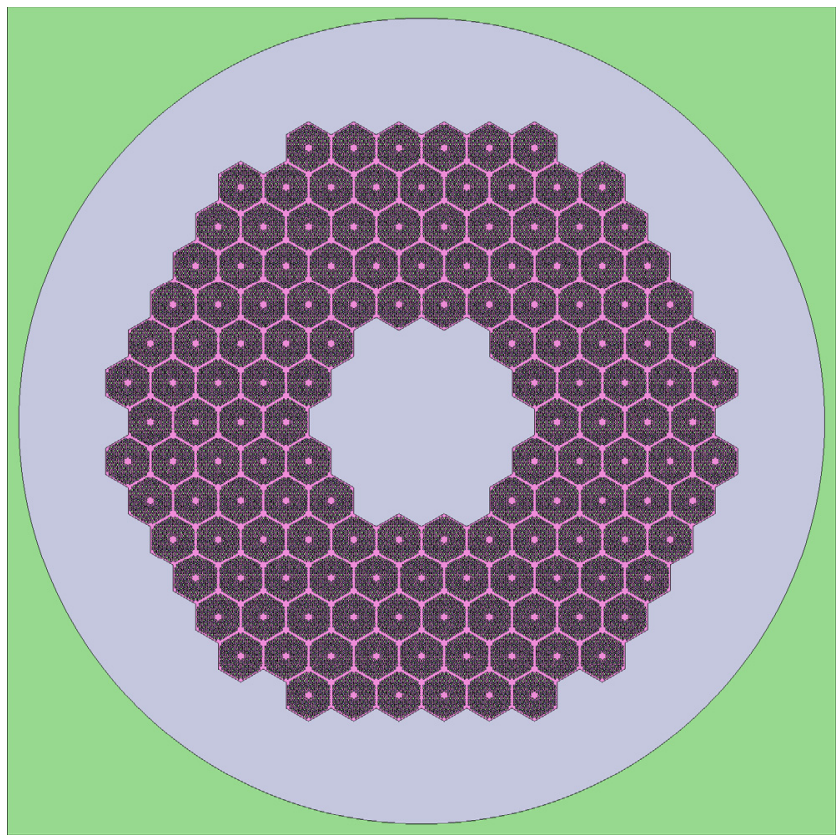

Figure 3-6. Diagram of 2D Serpent model of radial slice of DB-HTR core.

In the DB-HTR, there are only trace amounts of uranium. Therefore, the figure of merit chosen for determining an equivalent unit cell was capture in ${ }^{240} \mathrm{Pu}$ to fission in ${ }^{239} \mathrm{Pu}(\mathrm{c} 0 / \mathrm{f9})$. Figure 3-7 shows this figure of merit versus pitch of the unit cell model. A dashed line shows the whole-core value for $\mathrm{c} 0 / \mathrm{f} 9$. By this measure, the unit cell having pitch of $2.23 \mathrm{~cm}$ is equivalent to the whole-core value. This is the pitch that conserves the ratio of fuel to graphite in a single fuel block. This is due to the fact that with five fuel rings, the majority of fuel is away from reflector and can therefore be assumed to be in an infinite array of fuel blocks. Figure 3-8 shows the normalized neutron flux in the various unit cell sizes and the whole core model. This shows the similarity between the whole core and the unit cell having a $2.23 \mathrm{~cm}$ pitch. 


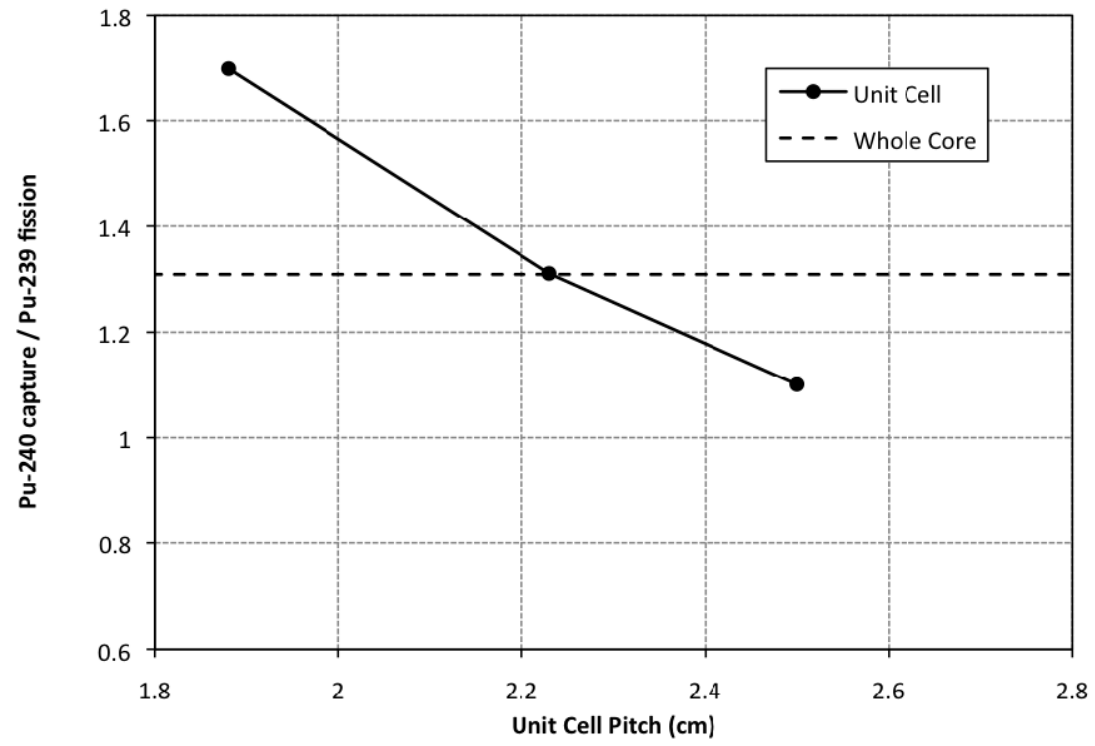

Figure 3-7. Ratio of $\mathrm{c} 0 / \mathrm{f} 9$ versus unit cell pitch with whole-core value shown for DB-HTR fuel.

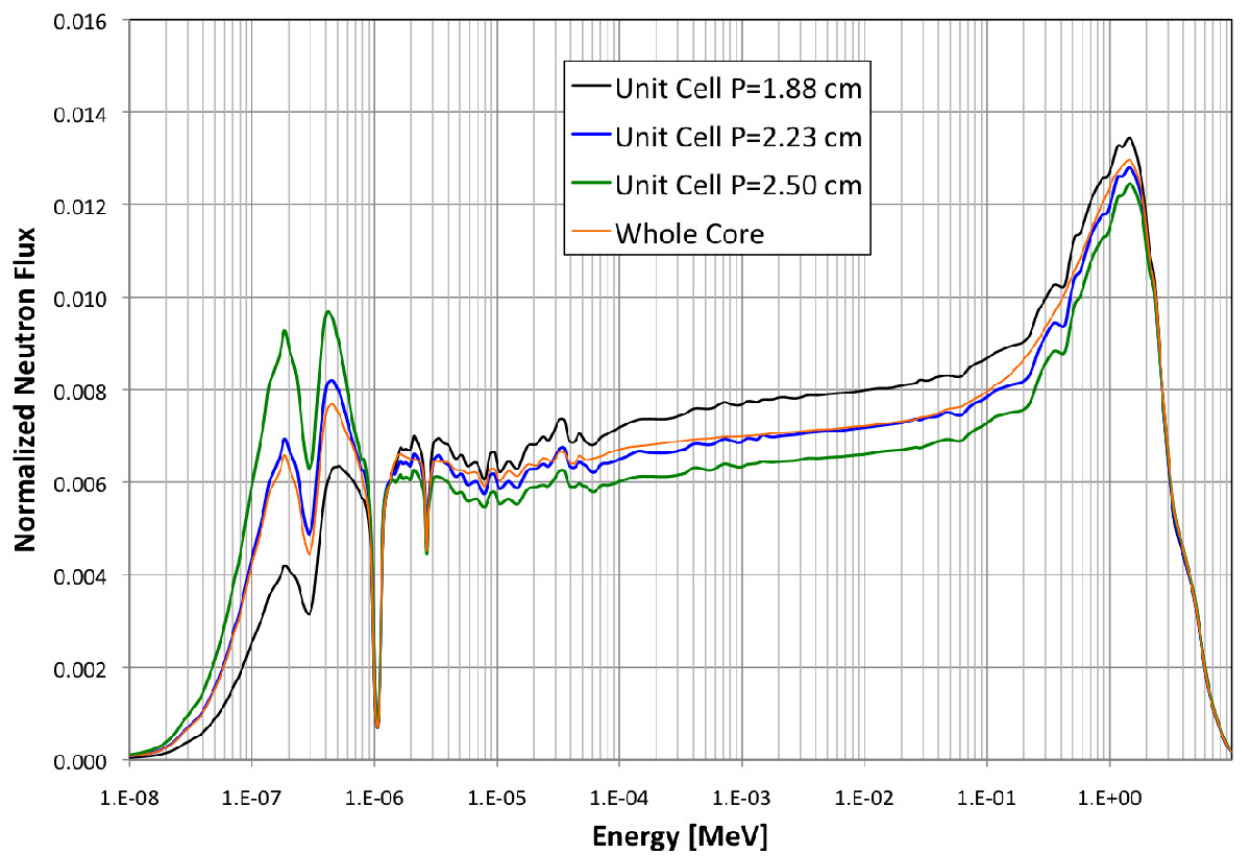

Figure 3-8. Normalized neutron flux spectra for various DB-HTR unit cell pitches with whole-core value shown.

\subsection{SCALE 6.1 Model}

The Transport Rigor Implemented with Time-dependent Operation for Neutronic depletion (TRITON) control module is developed and maintained by Oak Ridge National Laboratory as part of the SCALE package. [2] It was originally built around the two-dimensional arbitrary geometry discrete ordinates transport code NEWT. [11] TRITON serves as a controller for the sequencing of the different 
modules and the data transfer between them. Different code sequences exist within TRITON; the one used in these studies was T-DEPL. That sequence builds on the cross-section processing and 2-D neutron transport solution, and adds depletion capabilities.

The cross-section processing sequence in TRITON uses BONAMI, CENTRM/PMC and NITAWL. BONAMI [12] is a module that performs the Bondarenko calculations for the resonance self- shielding. CENTRM [13] computes a continuous-energy neutron spectrum by solving the transport equation using a combination of point-wise and multigroup data, which works in combination with PMC, [14] a module that produces multigroup data from point-wise. An alternative to CENTRM/PMC is the use of NITAWL, [15] a module that performs the Nordheim integral treatment for resonance self-shielding. The crosssections generated by combinations of these modules are then passed to NEWT for the neutronics calculations.

In a $T$-DEPL calculation, NEWT is used to create a three-group weighted library based on calculated volume-averaged fluxes for each mixture. COUPLE [16] is used to update the ORIGEN-S [17] crosssection library with cross-section data read from the weighted library. Three-group fluxes calculated by NEWT are supplied to ORIGEN-S for depletion calculations. COUPLE/ORIGEN calculations are repeated for each mixture being depleted, as specified in the input, using mixture-specific cross-section data and fluxes.

SCALE 6.1 models were developed for both the enriched uranium UCO (conventional HTR) case and the TRU-O 2 (DB-HTR) case. The pitch of the unit cell was $2.5 \mathrm{~cm}$ in the HTR case and 2.23 in the DBHTR case, as described in the previous section. The cells were hexagonal with reflected boundary conditions, as shown in Figure 3-9. For the DB-HTR case, the pitch is expanded to $2.5 \mathrm{~cm}$ from the $2.2264 \mathrm{~cm}$ shown in Figure 3-9. Each case was depleted to the discharge burnup assuming three batches and assuming linear reactivity change with burnup.

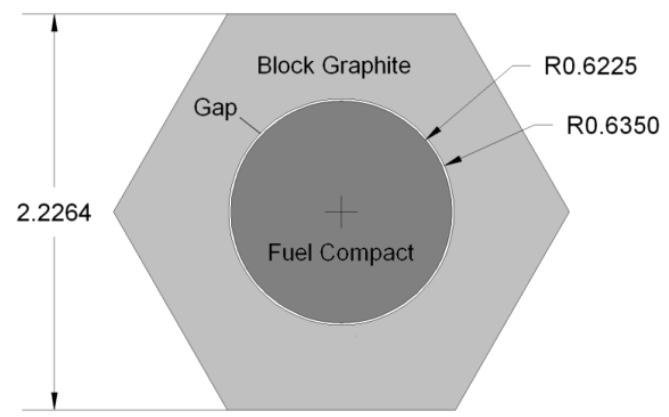

Figure 3-9. Unit cell constructed based on conserving the ratio of fuel compact to graphite in a single block.

\section{RESULTS}

\subsection{Conventional HTR Results}

The discharge burnup of the conventional UCO HTR fuel was fixed to $120 \mathrm{GWd} / \mathrm{MTiHM}$. In order to verify that this is feasible, a unit cell case was depleted in SCALE having a pitch equal to the the 2.23 $\mathrm{cm}$ value, which conserves the amount of graphite per fuel compact in a single block. Though it neglects a reactivity penalty from leakage and absorption in the reflector, this gives a reasonable first approximation of the reactivity-limited burnup of the fuel. Figure 4-1 shows $\mathrm{k}_{\infty}$ versus burnup in 
effective full power days (EFPD) for this cell. Figure 4-2 shows the same data versus burnup in $\mathrm{GWd} / \mathrm{MTiHM}$. With a $\mathrm{k}_{\infty}$ value crossing 1.0 at approximately $75 \mathrm{GWd} / \mathrm{MTiHM}$, and if one assumes behavior somewhat close to linear reactivity, fuel could reach an average discharge burnup of 120 $\mathrm{GWd} / \mathrm{MTiHM}$ assuming $n$-batch management where $2<n<3$, even with 2-3\% neutron leakage accounted for. Note that the case shown here with lattice pitch equal to $2.23 \mathrm{~cm}$ was only used to verify the achievable cycle length. The case with pitch $=2.5 \mathrm{~cm}$ was used to provide a better estimate of the appropriate burnup isotopics.

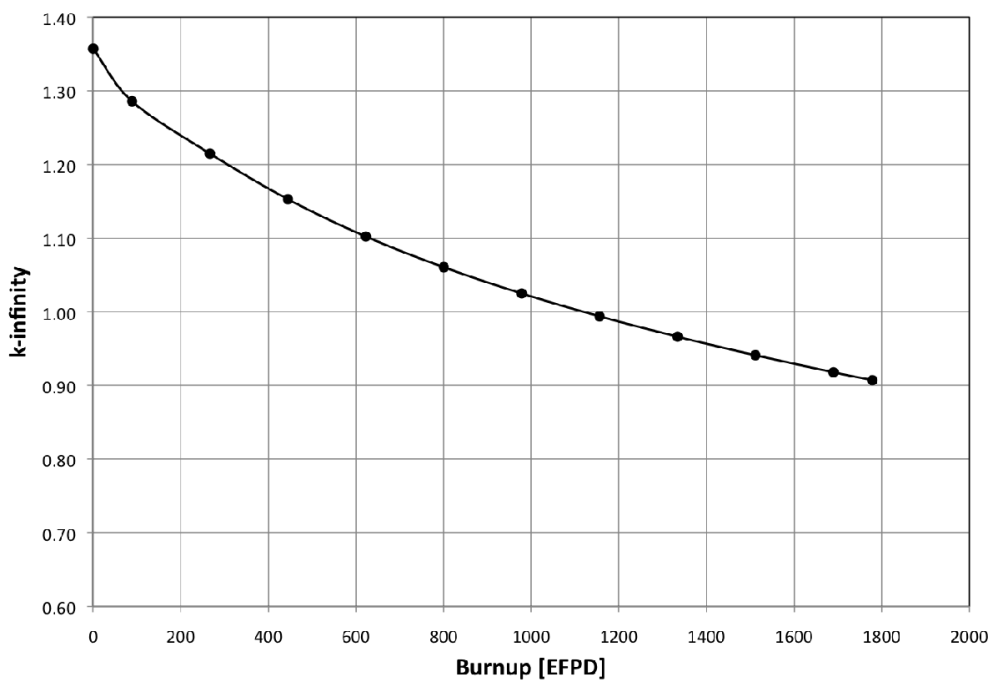

Figure 4-1. $\mathrm{K}_{\infty}$ versus burnup in EFPD for enriched uranium HTR unit cell with lattice pitch $=2.23 \mathrm{~cm}$.

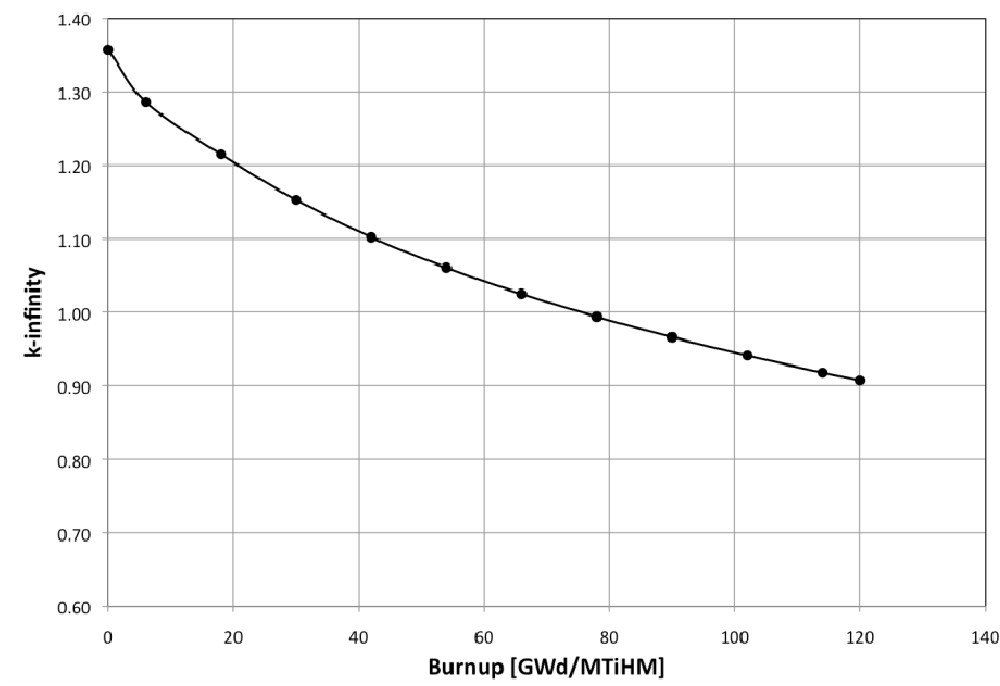

Figure 4-2. $\mathrm{K}_{\infty}$ versus burnup in GWd/MTiHM for enriched uranium HTR unit cell with lattice pitch = $2.23 \mathrm{~cm}$.

The SCALE output processing tool, OPUS, has a limit of the 500 most important nuclide mass fractions to write to output. These were written for the discharge burnup and transmitted to the fuel cycle analysis team. The SCALE cross-section extraction and editing module, XSECLIST, was used to write one-group 
fission, absorption, and radiative capture $(\mathrm{n}, \gamma)$ values versus burnup for the 1022 nuclides in the transmutation library. These were also transmitted to the fuel cycle analysis team. Table 4-1 shows mass fractions of the actinides present at discharge in the enriched UCO HTR case.

Table 4-1. Mass fractions of actinides at discharge for HTR case.

\begin{tabular}{|l|c|c|c|}
\hline \multicolumn{1}{|c|}{ Nuclide } & Mass Fraction & \multicolumn{1}{c|}{ Nuclide } & Mass Fraction \\
\hline Th-228 & $4.34 \mathrm{E}-11$ & $\mathrm{Pu}-238$ & $9.73 \mathrm{E}-04$ \\
\hline $\mathrm{Th}-230$ & $2.59 \mathrm{E}-08$ & $\mathrm{Pu}-239$ & $1.47 \mathrm{E}-02$ \\
\hline $\mathrm{Th}-232$ & $1.83 \mathrm{E}-08$ & $\mathrm{Pu}-240$ & $5.22 \mathrm{E}-03$ \\
\hline $\mathrm{Pa}-231$ & $6.23 \mathrm{E}-09$ & $\mathrm{Pu}-241$ & $6.44 \mathrm{E}-03$ \\
\hline $\mathrm{Pa}-233$ & $1.11 \mathrm{E}-10$ & $\mathrm{Pu}-242$ & $2.59 \mathrm{E}-03$ \\
\hline $\mathrm{U}-232$ & $5.30 \mathrm{E}-09$ & $\mathrm{Pu}-243$ & $5.16 \mathrm{E}-07$ \\
\hline $\mathrm{U}-233$ & $6.60 \mathrm{E}-09$ & $\mathrm{Pu}-244$ & $7.86 \mathrm{E}-08$ \\
\hline $\mathrm{U}-234$ & $2.09 \mathrm{E}-03$ & $\mathrm{Am}-241$ & $2.82 \mathrm{E}-04$ \\
\hline $\mathrm{U}-235$ & $5.83 \mathrm{E}-02$ & $\mathrm{Am}-242$ & $6.02 \mathrm{E}-07$ \\
\hline $\mathrm{U}-236$ & $2.20 \mathrm{E}-02$ & $\mathrm{Am}-242 \mathrm{~m}$ & $5.96 \mathrm{E}-06$ \\
\hline $\mathrm{U}-237$ & $3.19 \mathrm{E}-05$ & $\mathrm{Am}-243$ & $6.35 \mathrm{E}-04$ \\
\hline $\mathrm{U}-238$ & $8.84 \mathrm{E}-01$ & $\mathrm{Am}-244$ & $2.36 \mathrm{E}-08$ \\
\hline $\mathrm{U}-239$ & $1.21 \mathrm{E}-06$ & $\mathrm{Am}-244 \mathrm{~m}$ & $1.52 \mathrm{E}-08$ \\
\hline $\mathrm{Np}-236$ & $1.62 \mathrm{E}-10$ & $\mathrm{Cm}-242$ & $9.61 \mathrm{E}-05$ \\
\hline $\mathrm{Np}-237$ & $2.19 \mathrm{E}-03$ & $\mathrm{Cm}-243$ & $2.27 \mathrm{E}-06$ \\
\hline $\mathrm{Np}-238$ & $4.60 \mathrm{E}-06$ & $\mathrm{Cm}-244$ & $2.08 \mathrm{E}-04$ \\
\hline $\mathrm{Np}-239$ & $1.75 \mathrm{E}-04$ & $\mathrm{Cm}-245$ & $1.55 \mathrm{E}-05$ \\
\hline $\mathrm{Np}-240$ & $1.25 \mathrm{E}-09$ & $\mathrm{Cm}-246$ & $9.16 \mathrm{E}-07$ \\
\hline $\mathrm{Np}-240 \mathrm{~m}$ & $2.49 \mathrm{E}-10$ & $\mathrm{Cm}-247$ & $8.94 \mathrm{E}-09$ \\
\hline $\mathrm{Pu}-236$ & $1.07 \mathrm{E}-09$ & $\mathrm{Cm}-248$ & $5.38 \mathrm{E}-10$ \\
\hline $\mathrm{Pu}-237$ & $1.84 \mathrm{E}-10$ & & \\
\hline
\end{tabular}

Three different conversion ratios were also tabulated according to the definitions given in the Transmutation Library. TRU Conversion Ratio is a measure of production rate of TRU to destruction of TRU by fission, given by;

$$
\text { TRU Conversion Ratio }=\frac{\sigma_{n, \gamma}^{U^{236}} w^{U^{236}}+\sigma_{n, \gamma}^{U^{238}} w^{U^{238}}}{\sum_{N p^{23} \rightarrow C f^{252}} \sigma_{f i s i o n}^{i} w^{i}}
$$

where $w$ is mass fraction of that nuclide.

The TRU "Class" Conversion Ratio is the ratio of captures in heavy nuclides $\geq{ }^{236} U$ to captures and fissions in TRU, given by;

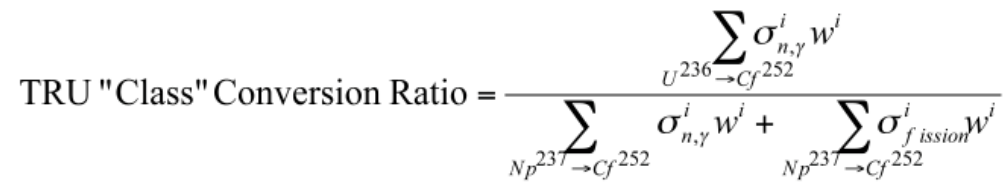


The Fissile Breeding Ratio is the ratio of the rate of production of odd heavy metal nuclides to loss of odd heavy metal nuclides by either fission or capture to an even nuclide. This is given by;

Fissile Breeding Ratio $=\frac{\sigma_{n, \gamma}^{U^{234}} w^{U^{234}}+\sigma_{n, \gamma}^{U^{236}} w^{U^{236}}+\sigma_{n, \gamma}^{U^{238}} w^{U^{238}}+\sigma_{n, \gamma}^{P u^{238}} w^{P u^{238}}+\sigma_{n, \gamma}^{P u^{240}} w^{P u^{240}}+\ldots}{\left(\sigma_{n, \gamma}^{U^{233}}+\sigma_{f i s s i o n}^{U^{233}}\right) w^{U^{233}}+\left(\sigma_{n, \gamma}^{U^{235}}+\sigma_{f i s s i o n}^{U^{233}}\right) w^{U^{235}}+\left(\sigma_{n, \gamma}^{P P^{239}}+\sigma_{f \text { ission }}^{P u^{239}}\right) w^{P u^{239}}+\left(\sigma_{n, \gamma}^{P u^{241}}+\sigma_{f i s s i n}^{P u^{241}}\right) w^{P u^{241}}+\ldots}$

In order to tabulate these, the one-group cross-sections tabulated and delivered to the transmutation analysis team were used along with mass fraction values calculated from the average of fresh and discharge content. Table 4-2 gives the results of this tabulation for the conventional HTR unit cell.

Table 4-2. Conversion ratios for conventional HTR unit cell.

\begin{tabular}{|l|c|}
\hline Parameter & Value \\
\hline TRU Conversion Ratio (Eq. 1) & 2.10 \\
\hline TRU “Class” Conversion Ratio (Eq. 2) & 1.56 \\
\hline Fissile Breeding Ratio (Eq. 3) & 0.542 \\
\hline
\end{tabular}

\subsection{DB-HTR Results}

The discharge burnup of the conventional TRU-O 2 DB-HTR fuel was selected to be 648 $\mathrm{GWd} / \mathrm{MTiHM}$, the value reported in Reference [6] for this particular fuel variant. As was previously discussed, in the DB-HTR case, the unit cell having a pitch equal to the $2.23 \mathrm{~cm}$ value not only conserves the amount of graphite per fuel compact in a single block, but it matches the figure of merit chosen for comparison to the whole core spectrum. Therefore, the same depletion model used for burnup isotopics can be used to estimate achievable burnup. Figure 4-3 shows $\mathrm{k}_{\infty}$ versus burnup in EFPD for this cell. Figure 4-4 shows the same data versus burnup in GWd/MTiHM. With a $\mathrm{k}_{\infty}$ value crossing 1.0 at approximately $540 \mathrm{GWd} / \mathrm{MTiHM}$, the discharge burnup of $648 \mathrm{GWd} / \mathrm{MTiHM}$ reported in Reference [6] is reasonable with 2 to 3 batch refueling and the resultant driving of subcritical assemblies. 


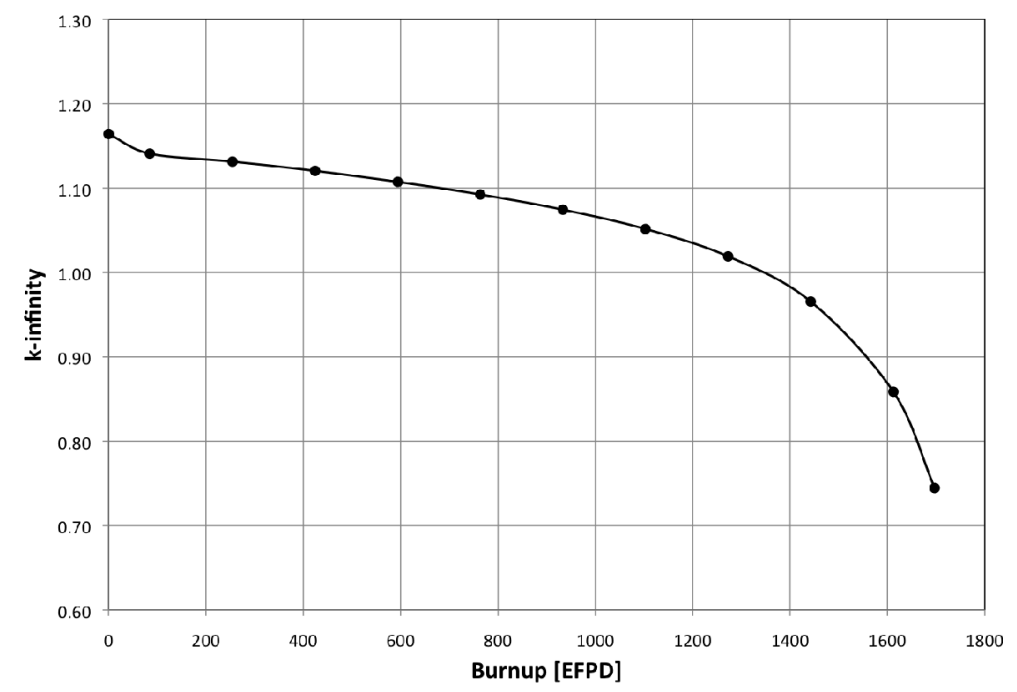

Figure 4-3. $\mathrm{K}_{\infty}$ versus burnup in EFPD for TRU-O ${ }_{2}$ fueled DB-HTR unit cell with lattice pitch $=2.23 \mathrm{~cm}$.

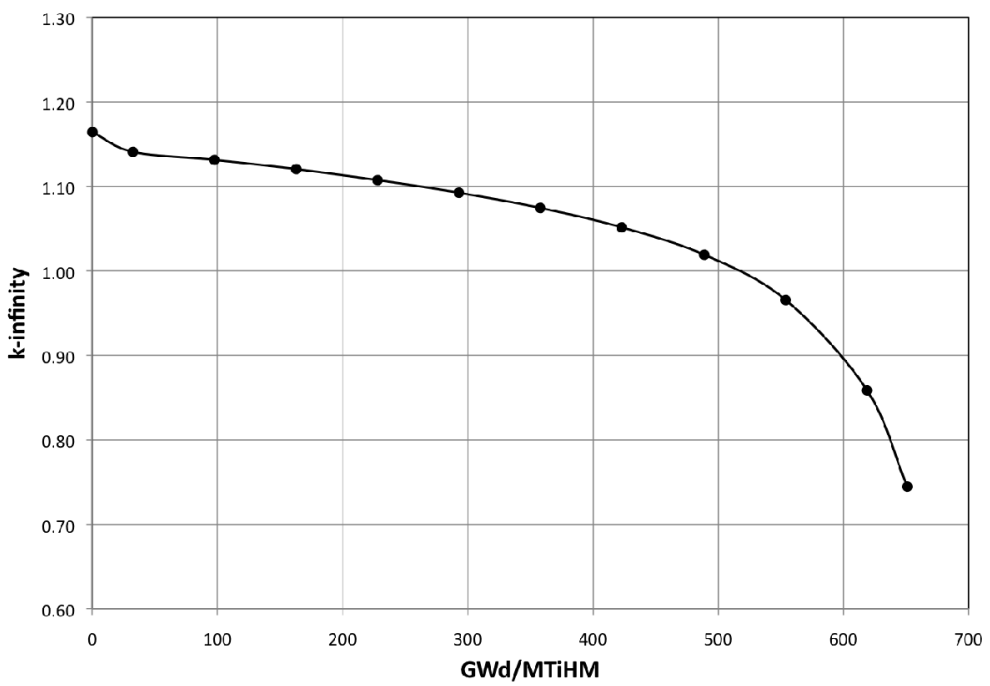

Figure 4-4. $\mathrm{K}_{\infty}$ versus burnup in GWd/MTiHM for TRU-O ${ }_{2}$ fueled DB-HTR unit cell with lattice pitch = $2.23 \mathrm{~cm}$.

The SCALE output processing tool, OPUS, has a limit of the 500 most important nuclide mass fractions to write to output. These were written for the discharge burnup and transmitted to the fuel cycle analysis team. The SCALE cross-section extraction and editing module, XSECLIST, was used to write one-group fission, absorption, and total cross-section values versus burnup for the 1022 nuclides in the transmutation library. These were also transmitted to the fuel cycle analysis team. Table 4-3 shows mass fractions of the actinides present at discharge in the TRU-only DB-HTR case. 
Table 4-3. Mass fractions of actinides at discharge for DB-HTR case.

\begin{tabular}{|l|c|l|c|}
\hline Nuclide & Mass Fraction & Nuclide & Mass Fraction \\
\hline Th-230 & $2.42 \mathrm{E}-08$ & Pu-243 & $9.54 \mathrm{E}-05$ \\
\hline Pa-231 & $3.16 \mathrm{E}-09$ & Pu-244 & $5.23 \mathrm{E}-05$ \\
\hline Pa-233 & $1.48 \mathrm{E}-09$ & Pu-245 & $3.21 \mathrm{E}-09$ \\
\hline $\mathrm{U}-232$ & $4.65 \mathrm{E}-08$ & Am-241 & $4.60 \mathrm{E}-03$ \\
\hline $\mathrm{U}-233$ & $4.73 \mathrm{E}-08$ & Am-242 & $4.65 \mathrm{E}-05$ \\
\hline $\mathrm{U}-234$ & $4.05 \mathrm{E}-03$ & $\mathrm{Am}-242 \mathrm{~m}$ & $1.06 \mathrm{E}-04$ \\
\hline $\mathrm{U}-235$ & $4.98 \mathrm{E}-04$ & $\mathrm{Am}-243$ & $1.33 \mathrm{E}-01$ \\
\hline $\mathrm{U}-236$ & $3.71 \mathrm{E}-04$ & $\mathrm{Am}-244$ & $9.73 \mathrm{E}-06$ \\
\hline $\mathrm{U}-237$ & $1.01 \mathrm{E}-06$ & $\mathrm{Am}-244 \mathrm{~m}$ & $6.03 \mathrm{E}-06$ \\
\hline $\mathrm{U}-238$ & $2.67 \mathrm{E}-06$ & $\mathrm{Cm}-242$ & $1.60 \mathrm{E}-02$ \\
\hline $\mathrm{Np}-236$ & $1.56 \mathrm{E}-09$ & $\mathrm{Cm}-243$ & $6.15 \mathrm{E}-04$ \\
\hline $\mathrm{Np}-237$ & $4.15 \mathrm{E}-02$ & $\mathrm{Cm}-244$ & $1.18 \mathrm{E}-01$ \\
\hline $\mathrm{Np}-238$ & $2.89 \mathrm{E}-04$ & $\mathrm{Cm}-245$ & $7.03 \mathrm{E}-03$ \\
\hline $\mathrm{Np}-239$ & $1.22 \mathrm{E}-06$ & $\mathrm{Cm}-246$ & $3.10 \mathrm{E}-03$ \\
\hline $\mathrm{Pu}-236$ & $6.05 \mathrm{E}-08$ & $\mathrm{Cm}-247$ & $5.99 \mathrm{E}-05$ \\
\hline $\mathrm{Pu}-237$ & $2.47 \mathrm{E}-08$ & $\mathrm{Cm}-248$ & $1.21 \mathrm{E}-05$ \\
\hline $\mathrm{Pu}-238$ & $1.53 \mathrm{E}-01$ & $\mathrm{Bk}-249$ & $5.82 \mathrm{E}-08$ \\
\hline $\mathrm{Pu}-239$ & $1.81 \mathrm{E}-02$ & $\mathrm{Cf}-249$ & $8.07 \mathrm{E}-09$ \\
\hline $\mathrm{Pu}-240$ & $7.41 \mathrm{E}-02$ & $\mathrm{Cf}-250$ & $5.94 \mathrm{E}-08$ \\
\hline $\mathrm{Pu}-241$ & $6.70 \mathrm{E}-02$ & $\mathrm{Cf}-251$ & $3.18 \mathrm{E}-08$ \\
\hline $\mathrm{Pu}-242$ & $3.59 \mathrm{E}-01$ & $\mathrm{Cf}-252$ & $7.93 \mathrm{E}-08$ \\
\hline
\end{tabular}

The three conversion ratios described by Equations 1-3 were also tabulated for the DB-HTR cell. These are given in Table 4-4. As expected, the TRU conversion ratio is very nearly zero since there is only trace uranium present at BOL.

Table 4-4. Conversion ratios for DB-HTR unit cell.

\begin{tabular}{|l|c|}
\hline Parameter & Value \\
\hline TRU Conversion Ratio (Eq. 1) & $1.8 \mathrm{E}-07$ \\
\hline TRU “Class” Conversion Ratio (Eq. 2) & 0.558 \\
\hline Fissile Breeding Ratio (Eq. 3) & 0.301 \\
\hline
\end{tabular}

\section{CONCLUSIONS}

Unit cell calculations were used to obtain discharge masses and one-group cross-sections for both the conventional enriched uranium HTR and the TRU-only DB-HTR. Unit cells were used to perform this analysis using SCALE 6.1. Unit cell sizes were first set by using Serpent calculations to match a spectral index between unit cell and whole core domains. In the case of the DB-HTR, the unit cell which was arrived at in this way conserved the ratio of fuel to moderator found in a single block of fuel. In the 
conventional HTR case, a larger moderator-to-fuel ratio than that of a single block was needed to simulate the whole core spectrum.

Discharge isotopics (for 500 nuclides) and one-group cross-sections (for 1022 nuclides) were delivered to the transmutation analysis team. This report provides documentation for these calculations. In addition to the discharge isotopics, one-group cross-sections were provided for the full list of 1022 nuclides tracked in the transmutation library. 


\section{REFERENCES}

1. Piet, Steven J., "Selection of Isotopes and Elements for Fuel Cycle Analysis," Advances in Nuclear Fuel Management IV (ANFM 2009), Hilton Head Island, South Carolina, USA, April 12 15 (2009).

2. DeHart, M.D., "TRITON: A Two-Dimensional Transport and Depletion Module for Characterization of Spent Nuclear Fuel," ORNL/TM-2005/39, Revision 5.1, Vol. I, Book 3, Section T1, November 2006.

3. Ortensi, et al., "Prismatic Coupled Neutronics/Thermal Fluids Transient Benchmark of the MHTGR-350 MW Core Design: Benchmark Definition," Obtained by private communication with Javier Ortensi, May 2012.

4. Idaho National Laboratory, “AGR-2 Data Qualification Interim Report,” INL/EXT-10-19676, September (2010).

5. M.A. Pope, J. Ortensi and A.M. Ougouag, "Evaluation of Supercells for Preparation of Homogenized Cross Sections for Prismatic Deep Burn VHTR Calculations," Proceedings of HTR 2010, Prague, Czech Republic, October 18-20 (2010).

6. Venneri, F., et al., "High Temperature Reactor (HTR) Deep Burn Core and Fuel Analysis: Design Selection for the Prismatic Block Reactor," Idaho National Laboratory Report, INL/EXT-1019973, September (2010).

7. Piet, Steven J., Private Communication, June 2012.

8. Massimo, L., Physics of High Temperature Reactors, Elsevier Science and Technology Books, 1976.

9. Leppänen, J. "PSG2/Serpent - A Continuous-energy Monte Carlo Reactor Physics Burnup Calculation Code: User's Manual," VTT Technical Research Centre of Finland, available at http://montecarlo.vtt.fi, September 5, 2011.

10. Briesmeister, J.F., "MCNP_A General Monte Carlo N-Particle Transport Code," Los Alamos National Laboratory, Los Alamos, New Mexico, 1997.

11. DeHart, M.D., "NEWT: A New Transport Algorithm for Two-Dimensional Discrete Ordinates Analysis in Non-Orthogonal Geometries," ORNL/TM-2005-39, Version 5.1, Vol. II, Book 4, Section F21, November, 2006b.

12. Greene, N.M., BONAMI: Resonance Self-Shielding by the Bondarenko Method, ORNL/TM2005/39, Version 5.1, Vol. II, Book 1, Section F1, November 2006.

13. Williams, M.L., Asgari, M. and Hollenbach, D.F., CENTRM: A One-Dimensional Neutron Transport Code for computing Pointwise Energy Spectra, ORNL/TM-2005/39, Version 5.1, Vol. II, Book 4, Section F18, November 2006.

14. Williams, M.L. and Hollenbach, D.F., PMC: A Program to produce Multigroup Cross Sections using Pointwise Energy Spectra from CENTRM, ORNL/TM-2005/39, Version 5.1, Vol. II, Book 4, Section F19, November 2006.

15. Greene, N.M., Petrie, L.M. and Westfall, R.M., NITAWL: Scale System Module for performing Resonance Shielding and Working Library Production, ORNL/TM-2005/39, Version 5.1, Vol. II, Book 1, Section F2, November 2006. 
16. Gauld, I.C. and Hermann, O.W., COUPLE: Scale System Module to process Problem-Dependent Cross Sections and Neutron Spectral Data for ORIGEN-S Analyses, ORNL/TM-2005/39, Version 5.1, Vol. II, Book 1, Section F6, November 2006.

17. Gauld, I.C., Hermann, O.W. and Westfall, R.M., ORIGEN-S: Scale System Module to calculate Fuel Depletion, Actinide Transmutation, Fission Product Buildup and Decay, and Associated Radiation Source Terms, ORNL/TM-2005/39, Version 5.1, Vol. II, Book 1, Section F7, November 2006. 